\title{
The Protection of the Rights of the Defendant by the Constitutional Court-The Kosovo Case
}

\author{
Adelina Rakaj \\ Faculty of Law, University of Prizren, Kosovo \\ E-mail: rakaj.adelina1@gmail.com
}

\begin{tabular}{|c|c|}
\hline ARTICLE INFO & Abstract \\
\hline \multirow{11}{*}{$\begin{array}{l}\text { Keywords: } \\
\text { Criminal proceedings; the rights of the } \\
\text { defendant; Constitution of the Republic } \\
\text { of Kosovo; ECHR; ECtHR } \\
\text { How To Cite: } \\
\text { Rakaj, A. (2020). The Protection of the } \\
\text { Rights of the Defendant by the } \\
\text { Constitutional Court-The Kosovo Case. } \\
\text { Nagari Law Review, 3(2), 1-13. }\end{array}$} & $\begin{array}{l}\text { The aim of this case study is to analyze the protection of the rights of the defendant } \\
\text { in criminal proceedings and the implementation of international standards on the } \\
\text { rights of the defendant in criminal proceedings in the domestic law of the Republic }\end{array}$ \\
\hline & in protecting the rights of the defendant during a criminal process, based on specific \\
\hline & cases decided by the Constitutional Court of the Republic of Kosovo. For more than \\
\hline & ten years since the Declaration of its Independence, Kosovo has established a legal \\
\hline & $\begin{array}{l}\text { system, which provides effective protection for the rights of a defendant. A } \\
\text { significant role in this regard was played by the fact that Kosovo directly applies }\end{array}$ \\
\hline & the jurisprudence of the International Court on Human Rights (ECtHR), as a \\
\hline & constitutional obligation. Out of all institutions of the legal system in Kosovo, \\
\hline & which are obliged to protect the rights of defendants, a determinant role was played \\
\hline & $\begin{array}{l}\text { by the Constitutional Court in such regards, therefore, this paper presents } \\
\text { arguments how the Constitutional Court of Kosovo has become a guardian for }\end{array}$ \\
\hline & $\begin{array}{l}\text { protection of the rights of defendants, in compliance with the Jurisprudence of the } \\
\text { ECtHR. }\end{array}$ \\
\hline & (C2020 NALREV. Faculty of Law Universitas Andalas \\
\hline
\end{tabular}

\section{Introduction}

Before analyzing the rights of the defendant in terms of legal guarantees in the Republic of Kosovo, firstly, the notion "defendant" will be clarified to the reader. The defendant implies the subject to whom the criminal procedure is conducted, so the defendant has a threefold meaning and is used for the defendant, the accused and the convict. ${ }^{1}$ In addition to these three subjects, the rights of the defendant are also valid for the arrested person who may also be potentially suspect, to whom the investigation or accusation is initiated; this logic is followed by the Criminal Procedure Code of the Republic of Kosovo. ${ }^{2}$ Regarding the notion of the defendant, the Criminal Procedure Code defines the notion of the defendant as "a person against whom criminal proceedings are conducted." In addition, in this code, the term "defendant" is also used as a general term for a "defendant," "accused" and "convicted

1 Sahiti Ejup , Murati Rrexhep (2016)., “Criminal Procedure Law”, Prishtina, pp.157

2 Usually, authors, the moment of arrest refer to as "pre-trial proceedings," see more: Flynn, A., Hodgson, J., Mcculloch, J., \& Naylor, B. (2016). “Legal Aid and Access to Legal Representation: Redefining The Right to A Fair Trial”. Melbourne University Law Review, 40(1), 207-239. pp. 227 
person." 3 In the context of protecting the rights of the defendant, the Republic of Kosovo provides three legal bases for the protection of the rights of the defendant. These legal bases are the international acts applicable in the Republic of Kosovo and the judicial practice of the ECHR, the Constitution of the Republic of Kosovo and the judicial practice of the Constitutional Court of Kosovo, and the applicable criminal legislation. Regarding the international acts which guarantee some of the rights of the defendant, the Republic of Kosovo represents the model of the states which have offered a very advanced position of international acts within the domestic legal order. Article 22 of the Constitution of the Republic of Kosovo determines that some of the international instruments, which also guarantee the rights of the defendant, are directly applicable in the Republic of Kosovo. ${ }^{4}$ Based on the status that international acts have, according to the Constitution of the Republic of Kosovo (Article 22), it is understood that they have priority over other legal acts, which means that their validity is straightforward in the legal order of the Republic of Kosovo. Moreover, the Republic of Kosovo has ratified these conventions through the constitution, hence the same conventions are considered part of the domestic legal order, and in terms of the hierarchy have power over the laws. Based on the principle of direct implementation of international acts, as seen in Article 22 of the Constitution of the Republic of Kosovo, as long as these acts regulate the rights of the defendant, they also provide guarantees for respecting these rights in the Republic of Kosovo. 5 Two of the most important acts, part of the international instruments of Article 22 of the Constitution of the Republic of Kosovo regulating the rights of the defendant are: the European Convention for the Protection of Human Rights and its Protocols (ECHR) and the International Covenant on Civil and Political Rights and its Protocols (ICCPR). On the protection and development of these guarantees provided by the Republic of Kosovo, regarding human rights, respectively the defendant's rights, the Constitutional Court has also played a dominant role. The Constitution of the Republic of Kosovo (2008) has defined an instrument on the protection of human rights and freedoms, which is the individual constitutional complaint 6 ; it constitutes a powerful mechanism of human rights guarantee.

\section{The protection of the rights of the defendant through the Constitutional Court}

Guaranteeing and protecting human rights and freedoms is a mission of any democratic country; therefore, in order to guarantee the effective protection of human rights, different countries have established constitutional courts through which they realize their protection. The Constitutional Court of the Federal Republic of Germany was among the first to include in its jurisdiction the examination of

3 Article 19, Criminal No. 04/L-123 Procedure Code, 28 December 2012, Official Gazette of the Republic of Kosova / No. 37 / 28 December 2012, Pristina.

4 Constitution of the Republic of Kosovo, 2008, Article 22. Among the eight conventions that are directly applicable in the Republic of Kosovo are as follows: (1) Universal Declaration of Human Rights; (2) European Convention for the Protection of Human Rights and Fundamental Freedoms and its Protocols; (3) International Covenant on Civil and Political Rights and its Protocols; (4) Council of Europe Framework Convention for the Protection of National Minorities; (5) Convention on the Elimination of All Forms of Racial Discrimination; (6) Convention on the Elimination of All Forms of Discrimination Against Women; (7) Convention on the Rights of the Child; (8) Convention against Torture and Other Cruel, Inhumane or Degrading Treatment or Punishment.

5 Morina Visar, Korenica Fisnik. and Doli Dren, (2011) "The relationship between international law and national law in the case of Kosovo: A constitutional perspective" I C CON Vol. 9 No. 1, 274-296, pp.294

6 Morina Visar, (2013) "Constitutional judiciary - Theoretical and Comparative Review", Prishtina, pp. 104-10 
individual complaints against public authorities for violations of constitutional human rights. ${ }^{7}$ Later, many constitutional courts have included in their jurisdiction the competence to review individual complaints to protect human rights and freedoms, such as Spain, Hungary, Macedonia, Croatia, the Czech Republic, Albania, Montenegro, and the Republic of Kosovo. ${ }^{8}$ Such constitutional control, as well as the protection of human rights and freedoms, has been recognized by the Constitutional System of Romania. ${ }^{9}$ The protection of human rights by the Constitutional Court of Romania comes out from the fact that the Constitution of Romania has established certain competencies for this court, including jurisdiction to review the constitutionality of the initiatives to review the constitution. ${ }^{10}$ So, in most states, the Constitutional Court, by a court of jurisdiction has turned into a court which is the defender of human rights and freedoms. ${ }^{11}$

3. The protection of the rights of the defendant by the Constitutional Court of the Republic of Kosovo

The Constitutional Court of the Republic of Kosovo has also established mechanisms that guarantee the protection of human rights. This mechanism, therefore, is the individual constitutional complaint, which is applied in case of any violations of human rights and freedoms by public authorities of the Republic of Kosovo. ${ }^{12}$ The demand of individuals for the protection of human rights can be sent to the Constitutional Court of Kosovo, always under the assumption of the exhaustion of legal remedies provided by the constitutional order of the country, in this case, Kosovo. ${ }^{13}$ Since its establishment, the Constitutional Court of Kosovo has dealt with a large number of cases of violations of human rights and freedoms, including cases of different legal nature, such as criminal, civil, administrative, etc. However, this paper covers only the role that the Constitutional Court of the Republic of Kosovo has had in protecting human rights, respectively protecting the rights of the defendant in the criminal process. Precisely, the rigorous application of legal remedies by the applicants for the protection of human rights, the Constitutional Court of the Republic of Kosovo, has also applied in criminal cases when it has examined the protection of constitutional rights. It is essential to note that the Constitutional Court has assessed differently the exhaustion of legal remedies when obtaining individuals' requests for protection of human rights. Moreover, there have been cases where legal remedies, even though exist, are ineffective, as is the case of returning to the point zero of the process of electing the chief prosecutor of the state, since it was found to be violation of human rights. ${ }^{14}$ Meanwhile, the same logic of reasoning, regarding the exhaustion of remedies, the Constitutional Court had used it in another case

7 Sadushi. Sokol (2012) "Drejtësia Kushtetuese në Zhvillim", (The Constitutional Justice in progress), Editions Toena, Tirana, pp.310.

8 Ibid, pg.310.

9 Daniela Cristina Valea "The role of the Romanian Constitutional Court in Protecting and Promoting Human Fundamental Rights and Freedoms", Procedia - Social and Behavioral Sciences 46 (2012) 5548 - 5552. pp.5549.

10 Ibid, pp.5550.

11 Traja Kristaq, (2000) “Drejtësia Kushtetuese”, (Constitutional Justice) Luarasi, Tiranë, pp.89.

12 Article 113.7, Constitution of the Republic of Kosovo, 2008.

13 Ibid

14 See: "The Constitutional Court of the Republic of Kosovo, Judgment in Cases No. KI99/14 and KI100/14, Shyqyri Syla and Laura Pula requesting constitutional review of the Decisions of the Kosovo Prosecutorial Council related to the election procedure of Chief State Prosecutor". http://gjk-ks.org/wpcontent/uploads/2014/07/KI99-14_ANG.pdf. 
involving violation of human rights in the procedure of electing the President of the Supreme Court. 15 However, in most of the cases decided, the Constitutional Court of the Republic of Kosovo has consistently maintained the principle that the parties should exhaust the remedies provided by the domestic legal order. ${ }^{16}$ Regarding the criminal cases reviewed by 2018, the Constitutional Court of Kosovo has decided in 201 cases with rulings of inadmissibility, mainly due to non-exhaustion of remedies, while only in seven (7) cases where the nature of the cases was criminal, it decided by a verdict, after finding violation of human rights and freedoms. In the framework of the judgments regarding the protection of human rights and freedoms in criminal proceedings, the Constitutional Court of the Republic of Kosovo has established several important standards, mainly based on the practice of the European Court of Human Rights (ECtHR), which is applied directly in the Republic of Kosovo, under Article 53 of the Constitution.

In the following, we present the cases of the Constitutional Court of the Republic of Kosovo, to see the arguments used when deciding on the protection of human rights in criminal proceedings.

\section{Case Bajrush Gashi - the objectivity of the decision}

One of the criminal cases ruled by the Constitutional Court of the Republic of Kosovo is the case of the Applicant Bajrush Gashi. ${ }^{17}$ The applicant, in 2009, was sentenced to four (4) years and four (4) months imprisonment, while the same sentenced person in 2011, made a request to the Supreme Court of the Republic of Kosovo for extraordinary mitigation of the sentence.

In 2011, the Supreme Court rejected as unfounded the request of Mr Bajrush Gashi. The Supreme Court ruled that the applicant's reasons for the request for extraordinary mitigation of the sentence were not of such nature that they would justify the extraordinary mitigation of the applicant's sentence. After that, Mr Bajrush Gashi submitted the case to the Constitutional Court, claiming that the Supreme Court violated Article 31 ( The Right to a Fair and Impartial Trial) of the Constitution and Article 6 (The Right to a Fair trial) ECHR. ${ }^{18}$ The applicant alleged that the Judge who was the presiding judge of the District Court in Prizren and decided his case also took part in the decision of the Supreme Court on his request for extraordinary mitigation of the sentence. ${ }^{19}$ Furthermore, the Judge in question did not inform the Supreme Court of the Republic of Kosovo that he was the Presiding Judge in District Court and decided on the same issue. ${ }^{20}$ According to the Provisional Criminal Procedure Code of Kosovo (PCPCK), the judge shall inform the president of the court about such circumstances. ${ }^{21}$ Furthermore, the impartiality of a court under Article 31 (Right to a Fair and Impartial Trial) of the Constitution and Article 6 (Right

15 The Constitutional Court of the Republic of Kosovo, Judgment in Case No. KI34/17, Constitutional review of Decision No. 50/2017 of the Kosovo Judicial Council of 06 March 2017. http://gjk-ks.org/wpcontent/uploads/vendimet/KI34-17_ANG_Judgment.pdf.

16 See more: Dissenting Opinion of Judge Gresa Caka-Nimani, Judgment in Case No. KI34/17, Constitutional Review of Decision No. 50/2017 of the Kosovo Judicial Council of 06 March 2017, paragraph 3. http://gjkks.org/wp-content/uploads/vendimet/KI34-17_ANG_AS\&BS_Mospajtues.pdf.

17 Constitutional Court of the Republic of Kosovo, Judgment in Case No. KI 06/12, Applicant Bajrush Gashi, Constitutional Review of the Decision of the Supreme Court, Pzd. no. 67/2011, dated 12 December 2011. http://gik-ks.org/wp-content/uploads/vendimet/gjk_ki_06_12_ang.pdf.

18 Ibid, paragraph 19.

19 Ibid, paragraph 17.

20 Ibid, paragraph 18.

21 Article 41, Provisional Criminal Procedure Code of Kosovo (PCPCK), Official Gazette. 6 July 2003. 
to a Fair Trial] of the ECHR must be determined according to a subjective test, that is on the basis of the personal conviction of a particular judge in a given case, and also according to an objective test, that is ascertaining whether the judge offered guarantees sufficient to exclude any legitimate doubt in this respect; within this standard was considered by the European Court on Human Rights (ECtHR), the case of Hauschildt v. Denmark 1989.22 In this case, the Constitutional Court of the Republic of Kosovo concluded among other things that "....the fear of lack of impartiality derives from the fact that the Judge in question, as the Presiding Judge in the District Court of Prizren, sentenced the applicant to a penalty of imprisonment. This same judge was also a member of the Supreme Court Panel when it ruled that the request of the applicant for extraordinary mitigation of the sentence was unfounded. ${ }^{23}$ Therefore, in these circumstances, the Constitutional Court justified the applicant's request and considered that Article 31 [Right to a Fair and Impartial Trial] of the Constitution and Article 6 [Right to a fair trial] of ECHR were violated. In this case, the Constitutional Court decided that the case in question should be reconsidered. The main argument of this case raised by the Constitutional Court, was the failure of the regular courts, in issuing an objective decision, that was clearly contrary to the law.

\section{Case Bajrush Xhemajli -violation of the principle of equality of arms}

An important case, where the Constitutional Court of the Republic of Kosovo found violation of the rights of the defendant in criminal proceedings, was also the case of the applicant, Mr Bajrush Xhemajli (the defendant). ${ }^{24}$ The case was submitted to the Constitutional Court of Kosovo, as the defendant exhausted regular legal remedies provided by the legal order of the Republic of Kosovo. The defendant was involved in a traffic accident, which occurred on 21 May 2009; as a result, one person died. ${ }^{25}$ The criminal proceedings, in this case, were normally conducted and competent bodies such as the police and the state prosecutor collected all relevant evidence, including the expertise of the traffic expert. ${ }^{26}$ The traffic expert concluded that the defendant was the sole contributor to the accident. ${ }^{27}$ The applicant, respectively, the defendant, contested the expertise of the traffic expert in the Court for having shortcomings and because of other factors that might have contributed to the accident; including the technical condition of the vehicle, so he requested further clarifications from the expert, related to his expertise; the court approved his request. ${ }^{28}$ However, the applicant's proposal to order super expertise was rejected because the court considered that the traffic expert report and the provided clarifications by the expert were enough to assess the factual situation. ${ }^{29}$ Moreover, in his final statement, the applicant repeated once again his request to have super expertise. Despite this, on 26 November 2010, the District Court in Prishtina found the applicant guilty of committing the criminal offence. The

22 Case of Hauschildt v. Denmark (Application no. 10486/83) Judgment, Strasbourg, 24 May 1989, paragraph 46,47 and 48. https://hudoc.echr.coe.int/eng\#\{\%22itemid\%22:[\%22001-57500\%22]\}.

23 Constitutional Court of the Republic of Kosovo, Judgment in Case No. KI 06/12, Applicant Bajrush Gashi, Constitutional Review of the Decision of the Supreme Court, Pzd. no. 67/2011, dated 12 December 2011, paragraph 48. http://gjk-ks.org/wp-content/uploads/vendimet/gjk_ki_06_12_ang.pdf.

24 Constitutional Court of the Republic of Kosovo, Judgment in Case No. KI 78/12, Applicant Bajrush XhemajIi, Constitutional Review of the Supreme Court Judgment, Pkl. No. 70/2012, dated 22 June 2012. http://gjkks.org/wp-content/uploads/vendimet/gjkk_ki_78_12_v_ang.pdf.

25 Ibid, paragraph 15.

26 Ibid, paragraph 16-32.

27 Ibid, paragraph 33.

28 Ibid, paragraph 37.

29 Ibid, paragraph 38. 
evaluation of evidence is an important standard that is also established by the ECtHR. In Kraska v Switzerland, the European Court stated that "the effect of article 6.1 is to make possible to the competent court to conduct a proper examination of the submissions, arguments and evidence adduced by the parties, without prejudice to its assessment of whether they are relevant to its decision." 30 In Bonisch v. Austria, "the European Court found violation of Article 6.1 of the European Convention where it was difficult for the defence to obtain the appointment of a counter-expert." 31 Hence, a fair evaluation of evidence is very important for a court. One of the main arguments of the applicant was the manner of handling the evidence presented by him, especially, his request for super-expertise or new expertise. ${ }^{32}$ The Constitutional Court estimated that the traffic expert, in his expertise presented to the regular courts, mentioned factors that can contribute to traffic accidents: the human factor, the road factor and the vehicle factor, but he did not present the condition of the vehicle or the road. In this case, the Constitutional Court doubted the validity of the expertise presented by the expert and the need to supplement it. ${ }^{33}$ The Constitutional Court also emphasizes the repeated request of the applicant to reexamine the circumstances that caused the accident; thus making this fact an important argument in the context of the violation of human rights. ${ }^{34}$ The Constitutional Court analyzes this fact based on the framework of the principle of equality of arms and emphasizes that the "Equality of arms" principle requires that each party be afforded a reasonable opportunity to present its case under the conditions that do not place it at a substantial disadvantage vis-a.-vis another party. Although, there is no exhaustive definition as to what are the minimum requirements of "equality of arms", there must be adequate procedural safeguards appropriate to the nature of the case and corresponding to what is at stake between the parties. These may include opportunities to adduce evidence." 35

The Constitutional Court notes that the refusal by the court to nominate an expert, hear a witness or to accept other types of evidence might in certain circumstances render the proceedings unfair and violate the principle of "equality of arms."36 In this respect, there are two arguments in which the Constitutional Court of the Republic of Kosovo found a violation of human rights in the case of the applicant, Bajrush Xhemajli. The first argument is the fact that the court decided on the punishment of the Applicant, mainly based on the evidence of the injured party and the second argument is the refusal of the court for super expertise. According to the Court, "if a super expertise would have been ordered by the regular courts, it may have either confirmed the initial report of the traffic expert or confirmed the version of the applicant that there were other underlying factors involved in the cause of the traffic accident." Therefore, the Constitutional Court finds that in the applicant's case, there was a violation of human rights, respectively the right to a fair trial. In this respect, the Constitutional Court further notes that ... "in the light of these deficiencies in the handling of the evidence in the applicant's case, the Court finds

30 Case of Kraska C. Suisse (Application No. 13942/88 Judgment, Strasbourg, 19 April 1993, paragraph 30. https://hudoc.echr.coe.int/eng\#\{\%22itemid\%22:[\%22001-57828.\%22]\}.

31 Case of Bönisch v. Austria (Application no. 8658/79) Judgment Strasbourg 6 May 1985, paragraph 35. file:// / : /Users/Admin/Downloads/001-57443.pdf.

32 Constitutional Court of the Republic of Kosovo, Judgment in Case No KI 78/12, Applicant Bajrush Xhemajli, Constitutional Review of the Supreme Court Judgment, Pkl. No. 70/2012, dated 22 June 2012, paragraph 69. http://gjk-ks.org/wp-content/uploads/vendimet/gjkk_ki_78_12_v_ang.pdf.

33 Ibid, paragraph 75.

34 Ibid, paragraph 76.

35 Ibid, paragraph 89

36 Ibid, paragraph 96. 
that, when viewing the fairness of the criminal proceedings in the applicant's case as a whole, it cannot be said that he has benefitted from a 'fair trial' within the meaning of Article 6 ECHR and Article 31 of the Constitution." 37 Following these violations, the Constitutional Court of the Republic of Kosovo had remanded the case to the competent court based on the findings and the assessment of the evidence by the regular courts.

\section{Case Miodrag Pavic- the failure of courts to notify him of the sessions}

The third case deals with the case of Mr Pavic, who claimed that the Supreme Court violated the applicant's rights and freedoms guaranteed by Article 31 [Right to a Fair and Impartial Trial], in conjunction with Article 6 (Right to a Fair Trial) of the European Convention on Human Rights during the criminal proceedings. On 9 August 2016, the applicant submitted the request to the Court. ${ }^{38}$

The incident occurred in such a way that the applicant, through an indictment filed by the state prosecutor, was charged with a criminal offence of accepting bribes. On January 29, 2015, the Basic Court found the defendant innocent, stating that there was no convincing evidence that the defendant had committed the criminal offence. ${ }^{39}$ After the defendant was acquitted, the Prosecution filed an appeal against this judgment on the grounds of substantial violations of the provisions of the criminal procedure and incomplete determination of the factual situation. ${ }^{40}$ On 15 July 2015, the Court of Appeals held a session to consider the Prosecution's appeal and found the applicant guilty and sentenced him to imprisonment for one year; thus, modifying the judgment of the Basic Court. ${ }^{41}$ Furthermore, the defendant Miodrag Pavic was not notified of the Court of Appeal's session, in which he was found guilty. ${ }^{42}$ The defendant filed an appeal against the Judgment of the Court of Appeals claiming that the Court of Appeals did not notify the applicant of the session, and thus rendered the decision in violation of the CPCK. ${ }^{43}$ However, the Supreme Court rejected the defendant's appeal, arguing that the Court of Appeal, as a second instance, did not have an obligation to notify the defendant Mr Miodrag Pavic, but according to the Code of Criminal Procedure of the Republic of Kosovo, the accused should be notified. ${ }^{44}$ After the Supreme Court's decision, the defendant had exhausted all legal remedies and so decided to present the case to the Constitutional Court for the fact that the Court of Appeal found him guilty without allowing him to be present at its session; so he was not able to present his defence and arguments as a defendant. In this context, the defendant alleges that he did not have the opportunity to

37 Ibid, paragraph 105.

38 Constitutional Court of the Republic of Kosovo, Judgment in Case No. KI104/16, Applicant Miodrag Pavic Constitutional review of Judgment PML-KZZ. No. 110/2016, of the Supreme Court of Kosovo, 16 May 2016. http://gik-ks.org/wp-content/uploads/vendimet/gjk_ki_104_16_ang.pdf.

39 Constitutional Court of the Republic of Kosovo, Judgment in Case No. KI104/16, Applicant Miodrag Pavic Constitutional review of Judgment PML-KZZ. No. 110/2016, of the Supreme Court of Kosovo, 16 May 2016. http://gik-ks.org/wp-content/uploads/vendimet/gjk_ki_104_16_ang.pdf, paragraph 13-14.

40 Ibid, paragraph 15.

41 Ibid, paragraph 17.

42 Ibid, paragraph 16.

43 Ibid, paragraph 18.

44 Article 390, Criminal No. 04/L-123 Procedure Code, 28 December 2012, Official Gazette of the Republic of Kosova / No. 37 / 28 December 2012, Pristina. 
present his defence even though he was acquitted of all charges in the first instance. ${ }^{45}$ What is interesting in this case relates to the fact that even though the defendant had argued before the Supreme Court that the Court of Appeal did not invite him to its session, the Supreme Court did not assess the violation of constitutional rights, as defined in the ECHR. In Messeque and Jabardo v. Spain, the ECtHR noted that the criminal proceedings and the assessment of the evidence in this proceeding should be assessed as a whole and not separately. ${ }^{46}$ Moreover, it is very important to hear the other party, give arguments and to present a defence. However, the Constitutional Court, in the case of the defendant Miodrag Pavic, after analyzing the ECHR practice, noted that not all cases require an oral hearing at the appellate level. ${ }^{47}$ Among other things, the Constitutional Court affirms that an oral hearing may or may not be required, depending upon whether one is necessary to ensure a fair trial. ${ }^{48}$ However, in the case of the defendant, the question arises as to whether the rights of the defendant were violated because he was not notified of the hearings of the Court, although the defendant filed his request to the Supreme Court. In this context, the Constitutional Court of Kosovo assessed that according to the ECtHR case law, applied in Kosovo, the Court of Appeals should have invited the defendant to the hearing session at which his guilt was ruled. Hence, the defendant did not have the opportunity to present his defence for the accusations against him. The Court found that "... as a consequence of not being notified, the Court considers that in the proceedings before the Court of Appeals, the applicant was deprived of all rights and guarantees. He could not defend himself in person, did not have the opportunity to present his defence and to oppose the arguments of the other party, had no legal assistance, nor was he able to participate in the proceedings at the stage where the Court of Appeals found him guilty. Furthermore, this situation cannot be attributed to the applicant but falls within the responsibility of the competent court which did not notify him about the court session." 49 Thus, assessing the violation of the right to a fair trial, the Court decided to remand the case for reconsideration. The Constitutional Court of the Republic of Kosovo, in June 2018, ruled on two cases which resulted in a violation of the rights of the defendant in a criminal trial. One of the cases is when five (5) applicants were found guilty and therefore had the status of the defendant. The defendants, in this case, in the Constitutional Court, rejected or opposed the decision of the Supreme Court of the Republic of Kosovo, which found them guilty of certain criminal offences. 50 The main claim of the applicants, namely the defendants, was that the regular courts and the Supreme Court of the Republic of Kosovo had violated the defendant's rights

45 Constitutional Court of the Republic of Kosovo, Judgment in Case No. KI104/16, Applicant Miodrag Pavic Constitutional review of Judgment PML-KZZ. No. 110/2016, of the Supreme Court of Kosovo, 16 May 2016, http://gik-ks.org/wp-content/uploads/vendimet/gik_ki_104_16_ang.pdf, paragraphs 34-35.

46 Case of Barberà, Messegué and Jabardo V. Spain (Application no. 10590/83) Judgment Strasbourg 6 December 1988, paragraph 67-68. https:/ /hudoc.echr.coe.int/eng\#\{\%22itemid\%22:[\%22001-57429\%22]].

47 Constitutional Court of the Republic of Kosovo, Judgment in Case No. KI104/16, Applicant Miodrag Pavic Constitutional review of Judgment PML-KZZ. No. 110/2016, of the Supreme Court of Kosovo, 16 May 2016, paragraphs 43-48. http://gik-ks.org/wp-content/uploads/vendimet/gik_ki_104_16_ang.pdf.

48 Ibid, paragraph 45.

49 Constitutional Court of the Republic of Kosovo, Judgment in Case No. KI104/16, Applicant Miodrag Pavic Constitutional review of Judgment PML-KZZ. No. 110/2016, of the Supreme Court of Kosovo, 16 May 2016, http://gjk-ks.org/wp-content/uploads/vendimet/gik_ki_104_16_ang.pdf, paragraph 67.

50 Constitutional Court of the Republic of Kosovo, Judgment in Case No. KI146/17, KI147/1, 7, KI148/17, KI149/17 and KI150/17 Applicants Isni Thaçii, Zeqir Demaku, Fadil Demaku, Nexhat Demaku, and Jahir Demaku, Constitutional review of Judgment PML. KZZ. No. 322/2016 of the Supreme Court of Kosovo of 19 July 2017. content/uploads/2018/06/ki_146_17_147_17_148_17_149_17_150_17_agj_ang.pdf. 
guaranteed by Article 31 [Right to a Fair and Impartial Trial] of the Constitution of the Republic of Kosovo and Article 6 (Right to a Fair Trial) of the ECHR. ${ }^{51}$ The main argument of the defendants for a violation of the right to a fair and impartial trial was the improper assignment of judges in the trial panel and the reasoning of the decisions. ${ }^{52}$ The defendants alleged that the composition of the trial panel (which found them guilty) was assigned in contradiction with the rules for assigning judges, without a reasoned decision. The right to a reasoned decision is a very important dimension of the ECtHR case law. In this manner, in the Tatishvili case against Russia, the ECtHR, inter alia, assigns ..."for the proper administration of justice, judgments of courts and tribunals should adequately state the reasons on which they are based. Article 6.1 obliges courts to give reasons for their judgments, but cannot be understood as requiring a detailed answer to every argument. A further function of a reasoned decision is to demonstrate to the parties that they have been heard. "53 However, regarding a reasoned decision, the Constitutional Court of the Republic of Kosovo, inter alia, concluded: "Although the courts are not obliged to address all claims submitted by the applicants - they must, however - address claims that are central to their cases and which are raised in all stages of the proceedings as it happened in the present referral." 54 Given the fact that the court is not properly constituted, in the case of defendants in the Republic of Kosovo we can say that it is an essential violation of the provisions of criminal procedure if the court is not established by law. ${ }^{55}$ It is crucial to mention that the trial and conviction of the defendants in the regular court procedure was made by the international mission of the European Union in Kosovo, EULEX, which among other things, did not allocate judges based on the principle of objectivity and procedural safeguards, in accordance with the applicable Law No. 03 / L-053 on Jurisdiction, Case Selection and Case Allocation of EULEX Judges and Prosecutors in Kosovo. ${ }^{56}$ It is crucial to mention that the trial and conviction of the defendants in the regular court procedure was made by the international mission of the European Union in Kosovo, EULEX. Among other things, Eulex did not allocate judges based on the principle of objectivity and procedural safeguards, in accordance with the applicable Law No. 03 / L-053 on Jurisdiction, Case Selection and Case Allocation of EULEX Judges and Prosecutors in Kosovo. ${ }^{57}$ In the context of the trial and assessment of the defendants' argument, the Supreme Court had given the justification that the inadequate selection of judges in the trial panel did not contradict the procedural guarantees; the way of appointing judges was done according to the internal rules of the EULEX Mission. ${ }^{58}$ Among other things, in its judgment, the

51 Ibid, paragraph 4.

52 Ibid, paragraph 69.

53 Case Of Tatishvili V. Russia (Application no. 1509/02) Judgment Strasbourg 22 February 2007, paragraph 58. https://www.refworld.org/cases,ECHR,4667e2912.html.

54 Constitutional Court of the Republic of Kosovo, Judgment in Case No.KI13S/14 Applicant IKK Classic, Constitutional review of Judgment E. Rev. No. 21/2014 of the Supreme Court of Kosovo of 8 April 2014. http://gjk-ks.org/wp-content/uploads/2018/01/ki_97_16_agj_ang.pdf.

55 Article 384, paragraph 1.1, Criminal No. 04/L-123 Procedure Code, 28 December 2012, Official Gazette of the Republic of Kosova / No. 37 / 28 December 2012, Pristina.

56 Article 2, paragraph 2.6, Law No. 03 / L-053 on Jurisdiction, Case Selection and Case Allocation of EULEX Judges and Prosecutors in Kosovo.

57 Ibid.

58 Constitutional Court of the Republic of Kosovo, Judgment in Case No. KI146/17, KI147/17, KI148/17, KI149/17 and KI150/17Applicants Isni Thaçii, Zeqir Demaku, Fadil Demaku, Nexhat Demaku, and Jahir Demaku, Constitutional review of Judgment PML. KZZ. No. 322/2016 of the Supreme Court of Kosovo of 19 July 2017, $\quad$ paragraph $88 . \quad$ http://gjk-ks.org/wpcontent/uploads/2018/06/ki_146_17_147_17_148_17_149_17_150_17_agj_ang.pdf. 
Supreme Court did not explain why the Criminal Procedure Code had been violated and failed to give a reasoned decision to convince the parties. Therefore, the Constitutional Court finds that the Supreme Court failed to give a reasoned decision; thus violated the defendants' right to a fair and impartial trial. ${ }^{59}$ Likewise, in its judgment, the Constitutional Court stated that the right to a fair and impartial trial was violated by the fact that the appointment of the judges of the trial panel was not made on the basis of procedural safeguards. Therefore, in this case, the Constitutional Court decided to remand the case for reconsideration, without prejudging, the guilt or innocence of the defendants. 60

Another case, which was decided by the Constitutional Court of the Republic of Kosovo, was the case of the defendant Emine Simnica, who, on 30 May 2016, after being guilty, was convicted by the Basic Court for the criminal offence of cheating and distributing medicines.

The defendant was sentenced to a suspended sentence, and the court obliged the defendant to compensate for the material damage caused by the criminal offence committed; after that, the defendant paid the compensation. ${ }^{61}$ Against the sentencing judgment, in the case of the defendant, was the State Prosecutor. After his appeal, the Court of Appeals ruled to modify the suspended sentence to an effective imprisonment sentence, thus changing the first instance judgment. The defendant was against the decision of the Court of the Appeals. She submitted a request to the Supreme Court to annul the judgment and to impose a more mitigating sentence, as it was decided in the first instance court. The Supreme Court rejected her appeal, arguing that the defendant at all stages of the proceedings was represented by another lawyer, who submitted the appeal against the Judgment of the first instance. In the Supreme Court, the defendant was represented by another lawyer, who submitted the request for protection of legality; moreover, there was not any evidence that the lawyer was authorized. ${ }^{62}$ After the Supreme Court's decision, the defendant filed a request for annulment of the decision based on Article 442, paragraph 4, of the CPCK, which foresees that if the submission is not understandable or does not contain what is necessary to act in relation to the submission, the Court summons the party to fulfil or correct it. ${ }^{3}$ However, the Supreme Court rejected the defendant's request, without taking into consideration Article 442 of the Code of Criminal Procedure. 64 The defendant alleged that the Court of Appeals violated her right to a fair trial because it modified the judgment of the first instance court; moreover, the Supreme Court rejected her request, regardless given facts by the defendant. The Constitutional Court of the Republic of Kosovo noted that in the case of Emine Simnica, the Supreme Court rejected the request without analyzing the facts. According to the Supreme Court, the request was submitted by an unauthorized party. Moreover, the Supreme Curst failed to invite the defendant for additional clarifications related to her request. ${ }^{65}$ This argument, by the Constitutional Court, is referred to as denial of the defendant's right to access to the courts, a standard regarding the right to a

59 Ibid, paragraph 102

60 Ibid, paragraph 104

61 Constitutional Court of the Republic of Kosovo, Judgment in Case No.KI62/17 Applicant Emine Simnica, Constitutional review of Decision PN. II. No. 1/17 of the Supreme Court of Kosovo of 30 January 2017 related to the Decision PML. No. 300/16 of the Supreme Court of 12 December 2016. http://gjk-ks.org/wpcontent/uploads/2018/06/ki_62_17_agj_ang.pdf

62 Ibid, paragraphs 23-27.

63 Article 442, Criminal No. 04/L-123 Procedure Code, 28 December 2012, Official Gazette of the Republic of Kosova / No. 37 / 28 December 2012, Pristina.

64 Constitutional Court of the Republic of Kosovo, Judgment in Case No.KI62/17 Applicant Emine Simnica, paragraph 27.

65 Ibid, paragraph 41. http://gjk-ks.org/wp-content/uploads/2018/06/ki_62_17_agj_ang.pdf. 
fair and impartial trial under Article 31 of the Constitution of Kosovo and Article 6 of the ECHR. The ECtHR also defines "the right of access to a court" as a standard closely related to Article 6 of the ECHR. In the case Kreuz v. Poland, the ECtHR stated "...the Court reiterates that, as it has held on many occasions, Article 6.1 secures to everyone the right to have any claim relating to his civil rights and obligations brought before a court or tribunal." 66 In the context of the right of access to a court, among others, the Constitutional Court of Kosovo states that "...the right of access to a court means not only the right to initiate proceedings before a court but, in order for the right of access to a court to be effective, the individual must also have a clear and real possibility of challenging the decision which violates his/her rights." 67 In this respect, the Court notes that the defendant in the present case had access to the courts, as well as to the Supreme Court, but only until the moment of filing the request for protection of legality, for the fact that the Supreme Court should have previously summoned the defendant to correct or supplement the submission and not to reject it. The Court noted that the main reason for the rejection was that the defendant was not represented by the authorized representative, regardless of the basic facts and evidence. ${ }^{68}$ Given this argument, the Court considered that in such circumstances the defendant had been deprived of her right of access to a court as a principle of a fair and impartial trial under Article 31 of the Constitution and Article 6 of the ECHR. ${ }^{69}$ In this regard, the Court decided to remand the case to the Supreme Court for reconsideration.

\section{Conclusion}

The Constitutional Court of the Republic of Kosovo has been very active in the protection of human rights as provided by the Constitution of the Republic of Kosovo and international conventions. However, in the prism of protecting the rights of the defendant, in criminal proceedings, the Constitutional Court of the Republic of Kosovo has decided on merit in only five (5) cases, which we have elaborated above. Why the Constitutional Court has so far ruled for only five cases has nothing to do with the number of the applicants (parties), but has to do with the fact that the applicants (parties) in the Constitutional Court failed to argue for the exhaustion of remedies or failed to argue at the constitutional level the matter of the request. Based on the abovementioned cases, it is evident that the Constitutional Court in all cases, including those that it has rejected, relies on three or more cases decided by the ECtHR. These cases are directly applicable in the Republic of Kosovo. Also, the Constitutional Court becomes a guide to the implementation of the ECHR's practice, also for regular courts, guiding them in the way they are applied. In addition, it is clear that the Constitutional Court reviews and assesses the rights of the defendant within the right to a fair and impartial trial, although the defendants in the abovementioned cases complained about violations of other constitutional rights. Also, an important advantage of the Constitutional Court of Kosovo is the guarantee for the direct implementation of the constitutional order of Kosovo and the case law of the ECHR. Such a guarantee has greatly facilitated the work of the Constitutional Court but has also provided the defendants with a more effective defense of their rights in criminal proceedings. To sum up the paper, from the analysis of the above cases, especially in the case of Bajrush Xhemajli, the Constitutional Court has been very

66 Case Of Kreuz V. Poland (Application no. 28249/95) JUDGMENT Strasbourg 19 June 2001, paragraph 52.

67 Constitutional Court of the Republic of Kosovo, Judgment in Case No.KI62/17 Applicant Emine Simnica, paragraph 55. . http://gik-ks.org/wp-content/uploads/2018/06/ki_62_17_agj_ang.pdf.

68 Ibid, paragraph 60.

69 Ibid, paragraph, 76 
active, by rebuilding the arguments and the facts of the case to argue the violation of the rights of the defendant.

\section{Referrences}

Books

Traja Kristaq. 2000. Drejtësia Kushtetuese", (Constitutional Justice) Luarasi, Tirana.

Morina Visar. 2013. Constitutional judiciary - Theoretical and Comparative Review, Prishtina.

Sadushi Sokol. 2012. Drejtësia Kushtetuese në Zhvillim, (The Constitutional Justice in Progress), Editions Toena, Tirana;

Sahiti Ejup, Murati Rexhep. 2016. Criminal Procedure Law, Prishtinë.

\section{Journal}

Daniela Cristina Valea. 2012. "The Role of the Romanian Constitutional Court in Protecting and Promoting Human Fun-damental Rights and Freedoms", Pro-cedia - Social and Behavioral Sciences 46 (2012);

Flynn, A., Hodgson, J., Mcculloch, J., \& Naylor, B. 2016. “Legal Aid And Access To Legal Representation: Redefining The Right To A Fair Trial". Melbourne University Law Review, 40(1),

Morina Visar, Korenica Fisnik and Doli Dren. 2011. “The relationship between international law and national law in the case of Kosovo: A constitutional perspective," I•CON Vol. 9 No. 1 ,

\section{Court Cases and Decisions}

Case of Barberà, Messegué and Jabardo V. Spain (Application No. 10590/83) Judgment Strasbourg 6 December 1988;

Case of Bönisch V. Austria (Application No. 8658/79) Judgment Strasbourg 6 May 1985;

Case of Hauschildt V. Denmark (Ap-plication No. 10486/83) Judgment Strasbourg 24 May 1989;

Case of Kraska C. Suisse (Application No. 13942/88) Judgment, Strasbourg, 19 April 1993;

Case of Kreuz V. Poland (Application No. 28249/95) Judgment Strasbourg 19 June 2001.

Case of Tatishvili V. Russia (Application No. 1509/02) Judgment Strasbourg 22 February 2007;

Constitutional Court of the Republic of Kosovo, Judgment in Case No. KI 06/12, Applicant

Bajrush Gashi, Constitutional Review of the Decision of the Supreme Court, Pzd. no. 67/2011, dated 12 December 2011

Constitutional Court of the Republic of Kosovo, Judgment in Case No. KI 78/12, Applicant Bajrush XhemajIi, Constitutional Review of the Supreme Court Judgment, Pkl. No. 70/2012, dated 22 June 2012;

Constitutional Court of the Republic of Kosovo, Judgment in Case No. KI146/17, KI147/17, KI148/17, KI149/17 and KI150/17 Applicants Isni Thaçii, Zeqir Demaku, Fadil Demaku, Nexhat Demaku, and Jahir Demaku, Constitutional review of Judgment PML. KZZ. No. 322/2016 of the Supreme Court of Kosovo of 19 July 2017. 
Constitutional Court of the Republic of Kosovo, Judgment in Case No.KI13S/14 Applicant IKK Classic, Constitutional review of Judgment E. Rev. No. 21/2014 of the Supreme Court of Kosovo of 8 April 2014;

Dissenting Opinion of Judge Gresa Caka-Nimani, Judgment in Case No. KI34/17, Constitutional Review of Decision No. 50/2017 of the Kosovo Judicial Council of 06 March 2017;

The Constitutional Court of the Republic of Kosovo, Judgment in Cases No. KI99/14 and KI100/14, Shyqyri Syla and Laura Pula requesting constitutional review of the Decisions of the Kosovo Prosecutorial Council related to the election procedure of Chief State Prosecutor;

The Constitutional Court of the Republic of Kosovo, Judgment in Case No. KI34/17, Constitutional review of Decision No. 50/2017 of the Kosovo Judicial Council of 06 March 2017.

\section{Laws}

Criminal No. 04/L-123 Procedure Code, Official Gazette of the Republic of Kosova / No. 37 / 28 December 2012, Pristina. 